Preprints of the

Max Planck Institute for

Research on Collective Goods

Bonn 2014/15

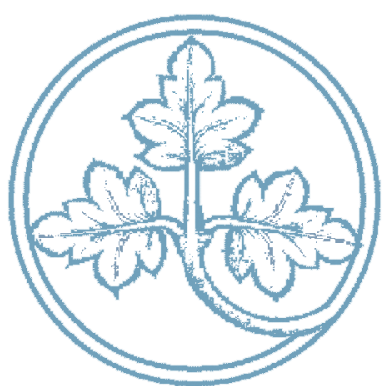

Sovereign Defaults,

Bank Runs, and Contagion

Stephan Luck

Paul Schempp

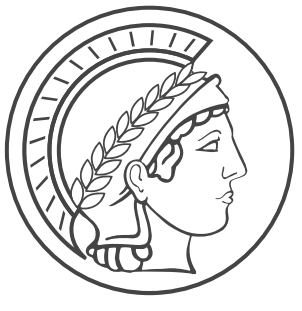




\title{
Sovereign Defaults, Bank Runs, and Contagion
}

\author{
Stephan Luck / Paul Schempp
}

September 2014 


\title{
Sovereign Defaults, Bank Runs, and Contagion*
}

\author{
Stephan Luck ${ }^{\dagger}$ and Paul Schempp ${ }^{\ddagger}$
}

We provide a model that unifies the notion of self-fulfilling banking crises and sovereign debt crises. In this model, a bank run can be contagious by triggering a sovereign default, and vice versa. A deposit insurance scheme can eliminate the adverse equilibrium only if the government can repay its debt and credibly insure deposits irrespective of the performance of the financial sector. Moreover, we analyze how banking crises and sovereign defaults can be contagious across countries. We give conditions under which the implementation of a banking union is effective and costless. Finally, we discuss the current proposals for a banking union in the euro area and argue that it should be extended by a supranational Deposit Guarantee Scheme.

Keywords: bank run, financial crisis, sovereign default, vicious cycle, financial contagion, banking union, deposit insurance

JEL codes: G21, G28, H63, H81

\footnotetext{
*We would like to thank Martin Hellwig for extensive advice and support. We also thank Brian Cooper, Christoph Engel, Patrick Bolton, Florian Buck, Falko Fecht, Wolfgang Kuhle, Alexander Morell, and Julian Schumacher, as well as conference and seminar participants of the MEF Workshop at the University of Bonn, the Econ Workshop at the MPI for Research on Collective Goods in Bonn, the Second Workshop in Financial Economics at the University of Mainz, the Spring Meeting of Young Economists in Aarhus, the North American Summer Meeting of the Econometric Society in Los Angeles, the European Summer Meeting of the Econometric Society in Gothenburg, the 30th Annual Meeting of the German Finance Association (DGF) in Wuppertal, and the CESifo Group Seminar in Munich. Financial support by the Alexander von Humboldt Foundation is gratefully acknowledged. ${ }^{\dagger}$ luck@coll.mpg.de, University of Bonn and Max Planck Institute for Research on Collective Goods.

${ }^{\ddagger}$ schempp@coll.mpg.de, University of Bonn and Max Planck Institute for Research on Collective Goods.
} 


\section{Introduction}

In this paper, we provide a model that unifies the notion of self-fulfilling banking crises and sovereign debt crises. We show how these crises can be contagious, i.e., how a bank run can trigger a sovereign default, and vice versa (first type of contagion). We discuss under which conditions a government is unable to eliminate self-fulfilling banking crises by implementing a deposit insurance scheme. Moreover, we illustrate how crises can be contagious across countries (second type of contagion), and how contagious crises can be prevented. This allows us to evaluate the efficacy of recent policy proposals for the implementation of banking union in the euro area. We show under which conditions a supranational Deposit Guarantee Scheme can eliminate self-fulfilling crises at not cost.

The sovereign debt crisis in the euro area which has accompanied and followed the recent financial crisis since early 2009 has made the interdependence of sovereign and financial stability a prominent topic in the academic and political debate. Farhi and Tirole (2014) state that danger of the feedback loop between banking crises and sovereign debt crises is an exceptionally uncontroversial economic idea. Several terrifying terms have been invented invented to describe this phenomenon, like "vicious cycle", "doom loop", "diabolic loop", or "deadly embrace".

However, this phenomenon is anything but new. Historically, sovereign defaults and banking crises have often preceded and accompanied each other (see, e.g., Reinhart and Rogoff, 2009, 2011), but most existing data concerns emerging economies. Furthermore, there have been surprisingly few formal models that help to guide our theoretical understanding of how sovereign defaults and banking crises are interrelated, in particular for the case of developed and highly leveraged economies. Only recent, theoretical models on this topic were provided, e.g., by Acharya et al. (2014), Farhi and Tirole (2014), Leonello (2013), Cooper and Nikolov (2013), and König et al. (2013).

Banking crises and sovereign debt crises have the common feature that they may result from coordination on a bad equilibrium. In a self-fulfilling bank run, depositors desire to withdraw all at once. This is an equilibrium because if all depositors desire to withdraw at once, it forces an otherwise solvent bank to engage in inefficient liquidation, leading to insolvency (see, e.g., Diamond and Dybvig, 1983, Goldstein and Pauzner, 2005). In a self-fulfilling sovereign debt crisis, investors roll over a sovereign's debt only at a high risk premium, or even refuse to do so. This constitutes an equilibrium as the high sovereign risk premium increases the government's debt burden and thereby the likelihood of a default (see, e.g., Calvo, 1988; Cole and Kehoe, 2000).

We present a simple banking model of maturity transformation in the tradition of Diamond and Dybvig (1983). In the first part of the paper, we consider the case of a closed 
economy. The model is reduced to a two-period version (we do not model the investment stage) and features consumers, banks, investors, and a government. We make two key assumptions: First, banks hold government bonds that they can sell in a secondary market in order to manage the liquidity needs of consumers. Second, the government's tax base is correlated with the real economic activity which in turn depends on the performance of the financial sector. The model features a strategic complementarity within the consumers' withdrawal decision, within the investors' decision to purchase government bonds, as well as across the decisions of the two types of agents. There exist two types of self-fulfilling equilibria in our model: The first one is a no-crisis equilibrium, in which government bonds trade at face value, and the government as well as the banks fulfill their obligations. The second one is a crisis equilibrium. In the crisis equilibrium, all consumers withdraw early, causing a bank run. Depending on the fiscal soundness of the government, a bank run can be accompanied by a rollover freeze and a sovereign default. If the government is fiscally weak, a banking crisis and a sovereign default aggravate and reinforce each other in a "vicious circle". Only if a government is fiscally strong, it can eliminate the crisis equilibrium by providing a deposit insurance.

In the second part of the paper, we extend our model to a multiple country setup where countries are interdependent, and we analyze cross-country effects of banking crises and sovereign debt crises. We assume that countries are interdependent due to banks diversifying their government bond holdings. If countries are sufficiently interdependent, self-fulfilling twin crises are contagious across borders. We show that if one country is fiscally weak while the other country is fiscally sound, it may be beneficial for both countries to pool their funds. The crisis equilibrium and its adverse consequences can be ruled out ex-ante by the following policy: Both countries form a banking union that implements a supranational deposit insurance scheme, and potentially also a fiscal union. By committing to repay the sovereign debt and to provide deposit insurance jointly, their joint promise will never be tested in equilibrium and is thus costless. A crucial insight is that forming such a union is not only beneficial for the fiscally weak country, but also for the fiscally strong country.

Guided by the insights of the model, we discuss two policy implications. The first policy implication concerns the design of the European Banking Union, with a special focus on the deposit insurance. Our model features cross-border costs of banking crises and sovereign defaults and points out channels through which a crisis in one country can trigger a crisis in another country. This in turn allows rationalizing policy responses by countries that are affected by foreign banking crises or sovereign defaults. The model allows us to give conditions under which a banking union (i.e., a joint deposit insurance) 
or the combination of a banking and a fiscal union can prevent contagious self-fulfilling banking crises and sovereign defaults. The model hence sheds light on the policy debates following the European debt crisis and allows us to investigate the efficacy of recent policy proposals (European Commission, 2013a). These proposals for a banking union focus on the Single Supervisory Mechanism (SSM) and the Single Resolution Mechanism (SRM). A supranational Deposit Guarantee Scheme (DGS) which would take the current national deposit insurance to a supranational level seems to be politically infeasible so far. By considering the self-fulfilling nature of banking crises, we show to what extend a banking union in its current form is ineffective at preventing such crises. Given that there are differences in the fiscal soundness of its member states, we argue that a banking union might only be effective if it comes with a joint deposit insurance.

The second policy implication concerns the regulatory treatment of banks holding government bonds. While there may be good reasons for banks to use government bonds as an instrument to manage liquidity needs 11 we show that this may also be a considerable source of fragility once there is a prospect of a government default. Fragility arises in our setup whenever the government's ability to repay its debt depends on the performance of the financial sector. This condition may be satisfied in developed economies that have highly leveraged financial systems. Our paper can therefore also be understood as a contribution to the debate concerning the liquidity regulation of banks. Regulatory frameworks typically facilitate the holding of government debt by intermediaries. The Basel Committee on Banking Supervision initially refrained from imposing any capital requirement for government bond holdings (see, e.g., Goodhart, 2011). Positive risk weights for poorly rated government bonds have been put on the agenda only recently, and were introduced in Basel III (Basel Committee, 2011). Our model provides an argument for why the exposure of banks to sovereign debt is a severe problem that is not adequately dealt with under both the current and the currently planned bank regulation.

This paper is structured as follows: Section 2 presents a model of a closed economy, derives the equilibria, and discusses the effect of a deposit insurance. In Section 3 , the model is extended to a two-country setting with international integration. We analyze contagion across countries and discuss optimal crisis prevention policies. Section 4 relates our findings to the current debate about the European Banking Union.

\section{Related Literature}

Our paper reaches out to the large literature on self-fulfilling banking crises (see, e.g., Diamond and Dybvig, 1983; Rochet and Vives, 2004; Goldstein and Pauzner, 2005) and

\footnotetext{
${ }^{1}$ See, e.g., Holmström and Tirole, 1998 , Gorton and Ordoñez, 2013, and Luck and Schempp, 2014.
} 
self-fulfilling sovereign debt crises (see, e.g., Calvo, 1988, Alesina et al., 1990, Cole and Kehoe, 2000), and attempts to unify some aspects of the two strands.

The first part of the paper is very closely related to a series of recent papers that model banking crises and sovereign debt crises in unified frameworks (Cooper and Nikolov, 2013 König et al., 2013 Leonello, 2013). Cooper and Nikolov also provide a model with multiple equilibria where the adverse equilibrium is characterized by a vicious cycle in which a government debt crisis and a banking crisis aggravate and reinforce each other. However, their focus is on the pricing of government debt, while emphasize the strategic complementarity of agents. The papers by König et al. and Leonello provide models featuring unique equilibria - reminiscent of Goldstein' (2005) twin crisis model - and they analyze how government guarantees affect financial stability and the government's ability to fulfill its obligation. All three papers have in common that the contagion from a banking crisis to a sovereign default originates from the increased public liabilities that arise from a safety net. In contrast, contagion in our setup arises because a financial crisis reduces the government's tax base and thus decreases its funding instead of increasing its expenditure. The channel from sovereign debt to banking crisis is similar, however, it results from banks hold government bonds.

With Acharya et al. (2014), we share the notion that the government's tax base is limited by a Laffer-curve property. Unlike our approach, they focus on the optimal redistribution (bailout) between a financial sector with debt overhang and a corporate sector. They find that a bailout can lose its bite if it lowers the value of government bonds that are held by the financial sector.

In the second part of the paper, we analyze how crises can be contagious across countries. This part is related to the literature on financial contagion and the spreading of banking panics (see, e.g., Allen and Gale, 2000; Dasgupta, 2004). In particular, the second part of this paper relates to Bolton and Jeanne (2011) who analyze the cross-border effects of sovereign defaults in financially integrated areas. In their model, government debt is used as collateral in interbank markets. Economic integration is beneficial as banks can diversify their government bond holdings, which fosters welfareincreasing interbank trade. However, this comes with possible contagion of a sovereign default ex-post, and fiscally strong countries might suffer from fiscal integration. Our paper is concerned with maturity transformation by banks and its inherent fragility, and not with the banks' role in allocating capital. Moreover, government defaults are endogenous in our setup and directly linked to the performance of the banking sector. In contrast to the results of Bolton and Jeanne, we find that fiscally strong countries might actually benefit from fiscal integration if this prevents self-fulfilling crises. 
Farhi and Tirole (2014) consider a model featuring fundamental financial and fiscal shocks in which banks hold domestic and foreign government bonds. Banks have an incentive to engage in excessive risk taking, particularly in collective moral hazard because the national government cannot commit to refrain from bailouts. This provides a new argument in favor of a banking union because the government is better off by delegating regulation to a supranational supervisor who takes a tough ex-post regulatory stance.

\section{Single-Country Model}

\subsection{Setup}

Consider an economy that goes through a sequence of two dates, $t \in\{1,2\}$. The economy is populated by a continuum of consumers of mass one and a continuum of investors of mass one. Moreover, there is a banking sector and a government. There exists a single good that can be used for both consumption and investment, and all units are denoted in terms of this good.

\section{Consumers}

Each consumer $i$ is endowed with a demand deposit contract $\left(c_{1}^{*}, c_{2}^{*}\right)$ that allows her either to withdraw $c_{1}^{*}$ units from her bank account in $t=1$ or $c_{2}^{*}$ units in $t=2$. Consumers have preferences as proposed by Diamond and Dybvig (1983). There are two types: a fraction $\pi \in[0,1]$ of consumers is impatient, while the remaining fraction $(1-\pi)$ is patient. Impatient consumers only derive utility from consuming early; their utility is given by $u\left(c_{1}\right)$. Patient consumers are indifferent between consuming early and late; their utility is given by $u\left(c_{1}+c_{2}\right)$. Types are private information of each consumer. Consumers face the decision to withdraw and to consume in $t=1$ or to withdraw and consume in $t=2$. Notice that the attributes "patient / impatient" characterize the consumer's exogenous types. In contrast, the attributes "late / early" will characterize the endogenous decision of consumers: an "early consumer" withdraws and consumes in $t=1$, while a "late consumer" withdraws and consumes in $t=2$. We denote the decision of each consumer $i$ to withdraw as well as to consume early with $\omega_{i} \in\{0,1\}$, where $\omega_{i}$ takes the value one if consumer $i$ withdraws in $t=1$. Let $\omega=\int_{0}^{1} \omega_{i} d i$ be the aggregate mass of early consumers.

\section{Banking Sector}

There is a banking sector that has the demand deposit contracts - which are the assets of consumers - as liabilities. It owns two types of assets: it holds government bonds as well as an illiquid portfolio of loans, both maturing at $t=2$. 
Banks are assumed to hold government bonds for the purpose of liquidity management. While we are not giving a micro-foundation for why banks are holding government bonds, we refer to various arguments for why financial intermediaries use government securities for liquidity management.

Government bonds are valuable as a medium of transfer across time (see, e.g., Gale, 1990 Woodford, 1990), and private agents may not be able to provide sufficient pledgable income (Holmström and Tirole, 1998). Furthermore, government securities - unlike private assets - are not subject to adverse selection (Gorton and Ordoñez, 2013), and government securities are simply less exposed to rollover risk than privately produced assets (Luck and Schempp, 2014).

In our model, banks are not considered to be agents. They behave mechanically in that they serve early-withdrawing consumers by selling government bonds to investors and by liquidating the illiquid assets if necessary. Having the demand deposit contracts as liabilities, banks need to serve a mass $\omega$ of consumers with $c_{1}^{*}$ units in $t=1$ each, and a mass $1-\omega$ of consumers with $c_{2}^{*}$ units in $t=2$. Banks own a stock of government bonds which mature in $t=2$. Bonds are liquid in the sense that they may be sold to investors in $t=1$. Selling these government bonds allow banks to fulfill their short-term liability, i.e., to serve early consumers. The total amount of government debt in the economy is given by $B$, and banks own a fraction $\alpha$ of them, i.e., they own $\alpha B<B$ units of government bonds. One unit of the government bond is a promise of the government to repay one unit of the good in $t=2$. Details of the government bonds will be further specified below.

Moreover, banks also own $I$ units of an illiquid asset to serve their long-term liabilities. The illiquid asset has an after-tax return of $r=(1-\tau) R>1$ in period two. The asset can be liquidated in $t=1$, yielding a return per unit of $\ell<1$. The fraction of illiquid assets which banks liquidate is denoted by $z$. The total return of liquidation is thus given by $z \ell I$. As indicated, the illiquid asset can be interpreted as a loan portfolio which pays off in the long run. In the short run, it can be liquidated at a substantial discount. The liquidation value $\ell$ can be interpreted as the price in the secondary market for the bank's loan portfolios and the discount may result from various frictions we do not model $\mathrm{f}^{2}$

\section{Government}

There is a government that has an outstanding amount of debt $B$, maturing in $t=2$. Like banks, the government is assumed to behave mechanically. The government always

\footnotetext{
${ }^{2}$ The assumption of low liquidation values is standard in the banking literature and may result from moral hazard (Holmström and Tirole, 1997), limited commitment of future cash-flows (Hart and Moore, 1994), adverse selection (Flannery, 1996), or uncertainty-averse investors (Uhlig, 2010).
} 
repays its debt if possible and defaults otherwise. In $t=2$, the government has an overall tax revenue of $T(z)=E+\tau(1-z) R I$ at its disposal. It consists of an exogenous tax revenue of $E \geq 0$, and an endogenous tax revenue $\tau(1-z) R I$ from taxation of the illiquid technology of the banking sector, where $\tau \in(0,1)$ is fixed. The tax revenue is used for the repayment of the government's debt $3^{3}$

We interpret the exogenous tax revenue $E$ as the tax revenue that the government generates irrespective of the performance of the banking sector. In turn, the endogenous tax revenue displays the fiscal revenue that depends on the performance of the banking sector and thus decreases in the level of liquidation $z$. It should thus be interpreted as the taxable economic activity that is generated through successful intermediation by banks. We assume that the government cannot raise any taxes in $t=1$. This clearly displays an extreme simplification. However, we argue that a government's ability to raise taxes at any point in time has natural limits $\mathbb{4}^{4}$ and we make the simplifying assumption that it is zero in the short run.

Importantly, we assume that the government repays its debt whenever $B \leq T(z)$. For simplicity we assume that it fully defaults otherwise. With this assumption, we deviate from large parts of the sovereign risk literature and completely abstract from willingness to pay considerations 5 However, we refer to recent contributions arguing that ability-to-pay constraints dominate willingness-to-pay considerations, especially in advanced economies with a high degree of leverage where defaults may trigger severe financial sector turmoil (Gennaioli et al., 2014; Acharya and Rajan, 2013). If the government cannot default selectively (Guembel and Sussman, 2009; Broner et al., 2010), its incentives to default are generally very weak whenever the costs of defaulting are very high for domestic creditors. Thus, a sovereign default in a leveraged economy is likely to result from a binding ability to pay constraint.

\section{Investors}

There is a continuum of investors of mass 1 . Each investor $j$ is equipped with one unit of the good in $t=1$. Investors are risk-neutral and do not discount. Investors buy government bonds from banks whenever their return is non-negative. Formally, the

\footnotetext{
${ }^{3}$ The remaining government budget can be used for other purposes. It could be used to provide a public good, or it could be transferred to the consumers. The exact use of remaining funds is not relevant in our model.

${ }^{4}$ See, e.g., the Laffer-curve property in Acharya et al. (2014).

${ }^{5}$ The literature on sovereign debt and risk has been shaped by the willingness to pay view, which argues that governments repay their debt when the costs of repayment are lower than the penalty expected for default. In the literature, default penalties have been argued to be, e.g., exclusion from capital markets or trade sanctions (see, e.g., Eaton and Gersovitz, 1981, Bulow and Rogoff, 1989).
} 
decision of an outside investor $j$ to purchase government bonds from banks at face value or not is denoted $\eta_{j} \in\{0,1\}$. It takes the value one if she is willing to buy a government bond at a price of one. Let $\eta=\min \left[\alpha B, \int_{0}^{1} \eta_{j} d j\right]$ be the aggregate mass of outside investors that buy government bonds at face value from banks.

In the following, we will refer to the purchase of government bonds by investors as rollover. Note that, in our setup, it does not matter whether the government needs to borrow $t=1$ in order to repay banks that hold bonds that mature in $t=1$ or whether banks need to sell government bonds that mature in $t=2$ in a secondary market in $t=1$. The first scenario clearly looks like a classical rollover problem. As both scenarios are equivalent, we use the expression rollover in order to simplify the wording.

\section{Parameters}

In the following, we make some restrictions on the model's parameters in order to ensure outcomes and effects in a relevant domain. The first three assumptions guarantee the existence of a no crises equilibrium (also referred to as type I equilibrium), while the last assumption ensures the existence of a crisis equilibrium (type II equilibrium).

Assumption 1. $c_{2}^{*} \geq c_{1}^{*}$

Assumption 1 guarantees that it is incentive-compatible for patient consumers to withdraw late and to consume in $t=2$ conditional on banks being able to pay out their promised payment, i.e., conditional on no liquidation.

Assumption 2. $\pi c_{1}^{*}=\alpha B \leq 1$ and $r I=(1-\pi) c_{2}^{*}$

The first equation of Assumption 2 ensures that banks can serve all impatient consumers by selling their government bond holdings at face value. The second equation ensures that all patient consumers can be served by the long-term return of the loan portfolio if they withdraw late. Moreover, $\alpha B \leq 1$ implies that investors have enough funds to purchase all government bonds from banks at face value.

Assumption 3. $T(0)=E+\tau R I \geq B$

Assumption 3 ensures that the government's tax revenue is sufficient to repay the government's debt given that there is no liquidation by banks.

Assumption 4. $(1-\pi) c_{1}^{*}>\ell I$

Assumption 4 implies that the banks will be insolvent and illiquid in $t=1$ in case all consumers withdraw early, irrespective of the government's solvency. The reason is that liquidation is sufficiently inefficient for a panic-based bank run to exist. While the patient 
consumers' claims might be met by selling the government bonds, Assumption 4 implies that if all patient consumers withdraw early, their claims equal to $(1-\pi) c_{1}^{*}$ cannot be met by proceeds of complete liquidation, $\ell I$. That is, the banking sector will be illiquid and insolvent in $t=1$ whenever there is complete withdrawal and liquidation.

\subsection{Outcomes}

In the following section, we show that the economy described above has two equilibria in pure strategies: a no crisis (type I) equilibrium and a crisis (type II) equilibrium. In the no-crisis equilibrium, only impatient consumers withdraw early and outside investors roll over the government's debt. In the crisis equilibrium, all consumers withdraw early, causing a bank run. Depending on the fiscal soundness of the government, a bank run can be accompanied by a sovereign default and a rollover freeze.

In order to derive the equilibrium outcomes, we first analyze the banks' liquidation of the loan portfolio for any given level of aggregate withdrawal and any rollover decision. We can then calculate the value of the demand deposit contract, as well as the value of government bonds in $t=2$, as functions of aggregate withdrawal and rollover. This in turn will pin down the optimal individual withdrawal and rollover decisions in $t=1$.

\section{Liquidation}

Banks have to fulfill their obligations in $t=1$ whenever possible. Recall that $\omega$ denotes the mass of consumers that withdraw early, and $\eta$ the mass of investors purchasing government bonds at face value. Banks need liquid funds of $\omega c_{1}^{*}$ in $t=1$, since they have to pay $c_{1}^{*}$ units of the good to a mass $\omega$ of consumers. Banks sell $\eta$ units of the governments bonds to investors. Given $\omega$ and $\eta$, banks must liquidate a fraction $z$ such that their liquid funds equal the demand for early consumption or engage in complete liquidation, $z=1$, otherwise. Liquidation $z$ is implicitly given by the budget equation $\omega c_{1}^{*}=\eta+z \ell I$ whenever feasible, or explicitly by

$$
z(\omega, \eta)=\min \left[1, \frac{\left[\omega c_{1}^{*}-\eta\right]^{+}}{\ell I}\right] .
$$

If banks can serve all withdrawing consumers by selling government bonds, liquidation is unnecessary. However, if the proceeds from selling government bonds are not sufficient to serve all withdrawing consumers, banks will have to engage in inefficient liquidation of the loan portfolio.

\section{Withdrawal and Rollover}

The individual decision of patient consumers to withdraw depends on the funds that banks have available in $t=2$. Similarly, the decision of investors to purchase government 
bonds depends on the funds that the government has available in $t=2$. Whenever there is liquidation, the amount left for late consumers and the tax revenue of the government decrease.

The deposit contract $\left(c_{1}^{*}, c_{2}^{*}\right)$ is characterized by promised payments. If there is liquidation, actual repayments $\left(c_{1}, c_{2}\right)$ may fall short of the promised levels. In period one, banks have to serve any withdrawing consumer with $c_{1}^{*}$ whenever possible. If banks engage in liquidation, this reduces the level of late consumption $c_{2}$, and if consumers in addition start to run on the banks, this also reduces $c_{1}$. For impatient consumers, it is dominant strategy to withdraw early, implying $\omega \in[\pi, 1]$. Given liquidation $z(\eta, \omega)$, the payments made to each patient consumer who is withdrawing late is given by

$$
c_{2}(z(\omega, \eta), \omega)=(1-z(\omega, \eta)) \frac{1-\pi}{1-\omega} c_{2}^{*} .
$$

A patient consumer only withdraws early if $c_{2}<c_{1}^{*}$ The optimal withdrawal decision of a patient consumer is therefore given by

$$
\omega_{i}^{*}(\omega, \eta)=\left\{\begin{array}{lll}
0 & \text { if } & c_{2}(z(\omega, \eta)) \geq c_{1}^{*} \\
1 & \text { if } & c_{2}(z(\omega, \eta))<c_{1}^{*} .
\end{array}\right.
$$

We can derive the optimal rollover decision in a similar fashion. Given $z(\eta, \omega)$, the government has a tax revenue of

$$
T(z(\omega, \eta))=E+\tau(1-z(\omega, \eta)) R I .
$$

The government repays its debt whenever the tax revenue $T(z(\eta, \omega))$ exceeds the government's outstanding debt $B$, and defaults otherwise. Investors purchase government debt at face value if the government will be able to repay its debt, and do not purchase if the government is expected to default. An investor's rollover decision is thus given by

$$
\eta_{i}^{*}(\omega, \eta)= \begin{cases}1 & \text { if } B \leq T(z(\omega, \eta)) \\ 0 & \text { if } B>T(z(\omega, \eta)) .\end{cases}
$$

The interrelation of the model's key variables is summarized in Figure 1. The left cycle is the well-known cycle that lies at the heart of a self-fulfilling bank run, as in the classic bank-run model by Diamond and Dybvig (1983): Increased liquidation lowers the level of funds available for late consumption. This in turn increases the incentive to withdraw early. High early withdrawal, however, further increases liquidation.7 The

\footnotetext{
${ }^{6}$ We define $c_{2}(1,1):=0$, i.e., the potential late consumption is zero in case of complete liquidation.

${ }^{7}$ For the sake of completeness, the dotted arrow represents a positive feedback effect of early withdrawal on late consumption: more consumers withdrawing early implies that the remaining available funds are distributed among a smaller mass of late consumers. This channel represents the same effect through which a bank run is welfare-increasing in Allen and Gale $(1998)$.
} 


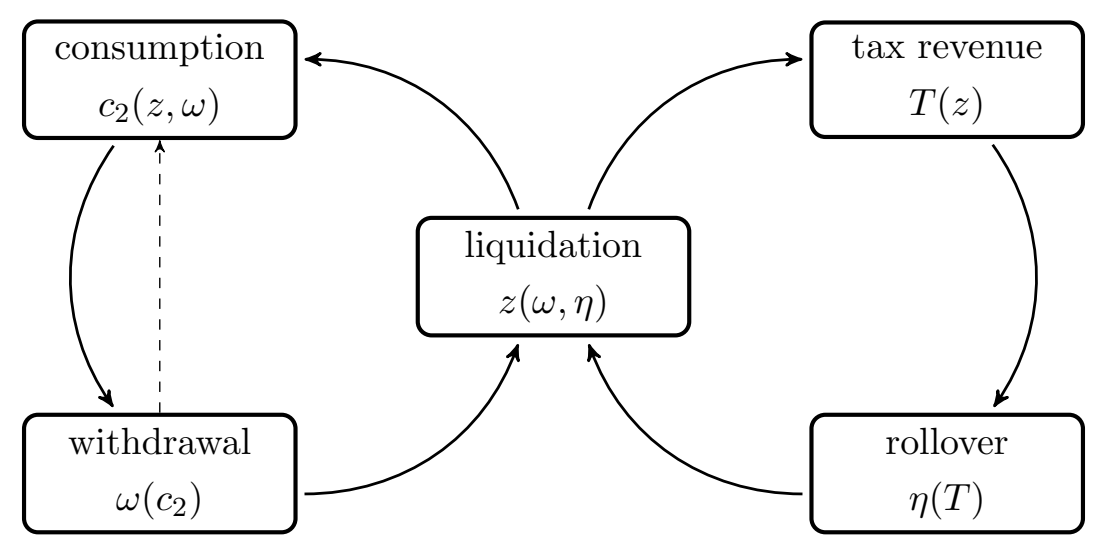

Figure 1: Interdependence of sovereign debt and banking.

right cycle shows how an anticipated sovereign default can be self-fulfilling: The inability of banks to sell government bonds forces them to liquidate some of the loan portfolio. Liquidation reduces the tax base and thus future tax revenue. This in turn may reduce the amount the government can repay. Consequentially, investors may become unwilling to purchase government bonds, forcing banks to liquidate even more.

The two cycles are connected through the liquidation of the illiquid loan portfolio. This allows a banking crisis to be contagious by triggering a sovereign debt crisis, and vice versa (1st type of contagion).

Definition 1. A Nash equilibrium in pure strategies is given by a set of consumers' withdrawal decisions $\left\{\omega_{i}\right\}$ and outside investors' rollover decisions $\left\{\eta_{j}\right\}$, such that these decisions are best responses, i.e., $\omega_{i}=\omega_{i}^{*}(\omega, \eta) \forall i$ and $\eta_{j}=\eta_{j}^{*}(\omega, \eta) \forall j$, where $\omega=$ $\int_{0}^{1} \omega_{i} d i$, and $\eta=\min \left[\alpha B, \int_{0}^{1} \eta_{j} d j\right]$.

We are now equipped in order to formulate the first result:

Proposition 1. The model has two Nash equilibria in pure strategies.

a) Type I equilibrium $(\omega, \eta)=(\pi, \alpha B)$ :

Only impatient consumers withdraw early, banks do not liquidate, the tax revenue is sufficient to repay creditors, and investors are willing to buy government bonds.

\section{b) Type II equilibrium}

$E<B$ Sovereign default and bank run $(\omega, \eta)=(1,0)$ : All consumers withdraw early and there is no rollover, inducing full liquidation. This results in illiquidity and insolvency of both the government and the banking sector. 
$E \geq B$ Bank run $(\omega, \eta)=(1, \alpha B)$ : Investors roll over government debt, but all consumers withdraw early. Although there is a bank run and full liquidation, the government is still able to fully serve its debt.

For the proof of Proposition 1, see the Appendix. The multiplicity of equilibria arises from the strategic complementarity between agents. There are three different components of strategic complementarity in the model. First, there is a strategic complementarity between consumers in their decision to withdraw: the more consumers withdraw, the higher the incentive for an individual consumer to withdraw as well. Second, there is strategic complementarity between the investors in their decision to purchase government bonds: more investors purchasing government bonds increases the individual incentive to purchase government bonds as well. Third, there is strategic complementarity across the two types of agents: higher levels of withdrawal decrease the incentive to roll over and vice versa.

Note that in the above setup both types of equilibria always exist. The type I equilibrium is always characterized by successful debt rollover and the absence of a panicbased bank run. The type II equilibrium is characterized by either a twin crisis where a sovereign default and a panic-based bank run accompany each other, or by a panic-based bank run without sovereign default. The type II equilibrium is a twin crisis whenever the exogenous tax base $E$ is less than the government's outstanding debt $B$, or if $E / B<1$. In this case, banking crises and sovereign debt crises are contagious in the sense that they aggravate and reinforce each other. Whenever $E$ exceeds $B$, i.e., $E / B \geq 1$, the government will be able to repay its debt irrespective of the occurrence of a banking crisis. In this case, a sovereign default will never occur, but a bank run still constitutes an equilibrium.

The parameter $E$ (or the ratio $E / B$ ) can be interpreted as a measure of the government's fiscal stability. If $E / B \geq 1$, the government can raise taxes irrespective of the performance of banks which will suffice to repay the outstanding debt. The taxable economic activity thus does not depend too much on the provision of financial services. If $E / B<1$, the government's ability to tax and to repay is closely linked to the banking sector, i.e., the taxable economic activity depends strongly on the performance of the banking sector. Therefore, whenever $E / B<1$, the crisis equilibrium is not only characterized by a banking crisis, but also by a sovereign default.

Generally, $E / B<1$ is reminiscent of the crisis zone in Cole and Kehoe (2000): when the exogenous tax base that is available irrespective of the performance of the banking sector is low, runs become possible. In the following, we will show that this may be true irrespective of the existence of a deposit insurance. 


\subsection{Deposit Insurance Scheme (DIS)}

We now analyze the effect of a deposit insurance. We define deposit insurance to be a guarantee by the government that each consumer receives $c_{1}^{*}$ units at a period of his choice. If the deposit insurance is credible, it prevents patient consumers from withdrawing early because in any contingency consumers get at least as much in period two as in period one. In the next paragraph, we will analyze under which conditions a deposit insurance is credible in our setup. We assume that the government uses its tax revenue to repay its bonds first, and only uses its remaining funds to fulfill the DIS afterwards if possible. This ordering might seem odd at first sight because government bonds only get repaid in period two, but the deposit insurance might already be needed in period one. However, since the government does not have funds in period one - recall that we assumed that the short-term tax base is zero - it will have to borrow in order to provide a DIS. The government will only be able to borrow and actually fulfill a deposit insurance if its outstanding debt is not already exceeding its available funds. Therefore, the government bonds are effectively senior to the deposit insurance.

The deposit insurance is credible if the government is able to repay its debt and to pay for the deposit insurance in any contingency. The most adverse contingency is the case in which all consumers withdraw early, and the banks thus have to engage in full liquidation. A sufficient condition for the deposit insurance to be credible is that the government can repay its debt $B$. Therefore, banks can sell their $\pi c_{1}^{*}$ bonds at face value. The complete liquidation of the illiquid loan portfolio provides the banks with an additional amount of $\ell I$ units. Thus, the deposit insurance has to cover the missing funds in order to serve the each consumer with $c_{1}^{*}$ units. Therefore, the maximal amount a deposit insurance might have to cover is given by $D I=c_{1}^{*}-\ell I-\pi c_{1}^{*}$.

Whenever $E \geq B+D I$, the deposit insurance scheme is credible, because the government can actually provide this amount in any contingency.

Proposition 2. By providing a deposit insurance scheme, the government can eliminate the crisis equilibrium iff $E \geq B+D I$.

The government is able to eliminate the crisis equilibrium whenever its exogenous tax revenue exceeds the sum of the outstanding debt $B$ and the maximum cost of a deposit insurance $D I$. In this case, it can repay its debt and credibly insure deposits of all consumers. The deposit insurance is never tested and therefore eliminates the adverse equilibrium at no costs. For $B \leq E<B+D I$, there are multiple equilibria. The government cannot prevent a bank run because the deposit insurance scheme is not credible, but since it can serve its debt, a rollover freeze does not occur in equilibrium. 
For $E<B$, the government can neither prevent a bank run nor a sovereign default. Figure 2 shows which type of equilibria exist for different levels of $E$ under the deposit insurance scheme.

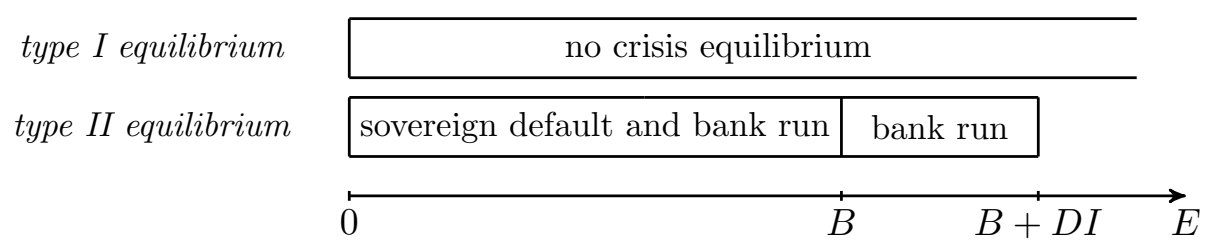

Figure 2: Existence of equilibria under the deposit insurance scheme. The type I equilibrium always exist. The type II equilibrium only exists if the deposit insurance is not credible, i.e., if $E<B+D I$. It is characterized by a bank run for $E \geq B$, and by a twin crisis for $E<B$.

Finally, notice that the deposit insurance does not bail out banks; it only steps in after banks have already defaulted on their liabilities. In fact, it would be more efficient in our model to bail out banks in order to prevent them from engaging in inefficient liquidation. However, in terms of preventing the crisis equilibrium, a bailout mechanism would have exactly the same effects as a DIS. The government could announce that it would bail out the banks in case of a crisis and thereby eliminate the crisis equilibrium if the announcement is credible. For this to be true, the government would need exactly the same budget, i.e., $B+D I$.

\section{Two-Country Model}

We now consider an extended, two-country setting of the model. This allows us to analyze under which conditions a crisis in one country may be contagious, triggering a crisis in another. We will use the setup to investigate which policies eliminate the adverse crisis equilibrium and ensure financial stability. In our model, a country consists of domestic consumers who hold demand deposit contracts with domestic banks. Furthermore, there is a government that taxes domestic economic activity. In our model, investors are not associated with countries.

Assume that there are two countries that are labeled home $H$ and foreign $F$. Without loss of generality, we take the view of the home country to facilitate the verbal interpretation of our analysis. Both countries are as described in the single-country case and identical to each other, except for some international financial interdependence. Furthermore, we vary the amount of exogenous tax revenue $E^{H}$ and $E^{F}$. A country 
$k$ is called fiscally sound whenever $E^{k}$ is very high, and fiscally weak whenever $E^{k}$ is low. We assume throughout most of this section that each country implements a deposit insurance scheme targeting domestic depositors whenever feasible. We analyze a policy setup where both countries can form a banking union or a fiscal and banking union. The banking union is a supranational policy tool that implements a joint deposit insurance for both countries. When tested, the costs are borne by the two countries jointly. We contrast these policies with a situation of political autarky where there is no supranational policy. Throughout the analysis, we maintain Assumptions 1 to 4 for both countries.

Importantly, we assume that countries are interdependent. We introduce interdependency by assuming that banks of both countries hold government bonds of both countries. While we assume this interdependence, we refer to empirical evidence as well as to theoretical explanations why government bond holdings are diversified 8

In a nutshell, we will present two main results: First, crises can be contagious across countries once there is interdependence. A sovereign debt crisis in the foreign country is always costly for the home country, and also triggers a crisis in the home country if the interdependence is sufficiently strong. Second, a fiscal and banking union may eliminate the adverse equilibrium at no costs if joint exogenous tax revenue is sufficiently high.

\subsection{Setup}

Assume that banks in both countries still hold a portfolio of government bonds. However, now this portfolio not only contains bonds of the domestic country, but also bonds of the other government. In both countries, banks hold an amount $(1-\lambda) \alpha B$ of the domestic and $\lambda \alpha B$ of the non-domestic government bonds, where $\lambda \in(0,1)$. The mass of investors who are willing to buy bonds of the respective government is denoted by $\eta^{H}$ and $\eta^{F}$. When buying government bonds, investors do not discriminate based on the nationality of banks selling the bonds.

As before, banks in the home country need to serve each early consumer with $c_{1}^{*}$ units in $t=1$, potentially forcing them to liquidate a fraction $z^{H}\left(\omega^{H}, \eta^{H}, \eta^{F}\right)$ of its loan portfolio. The budget equation of home banks in $t=1$ is therefore given by

$$
\omega^{H} c_{1}^{*}=(1-\lambda) \eta^{H}+\lambda \eta^{F}+z^{H} \ell I
$$

\footnotetext{
${ }^{8}$ For empirical evidence, see Bolton and Jeanne (2011) and Cooper and Nikolov (2013), who describe the cross-country holdings of government bonds in the euro area by using the European Banking Authority Stress Test data. Moreover, cross-country holdings of government bonds can result, e.g., from international activities of banks, or from diversification considerations (see, e.g., Bolton and Jeanne, 2011).
} 
whenever possible. In analogy to the single-country case we can express liquidation as

$$
z^{H}\left(\omega^{H}, \eta^{H}, \eta^{F}\right)=\min \left[1, \frac{\left[\omega^{H} c_{1}^{*}-(1-\lambda) \eta^{H}-\lambda \eta^{F}\right]^{+}}{\ell I}\right] .
$$

Observe that, in contrast to the single country case, home banks' liquidation is now not only a function of aggregate withdrawal and aggregate rollover in the home country, but also a function of aggregate rollover of the foreign country's sovereign debt. Late consumption and tax revenue are given as above: they are functions of the liquidation fraction, $c_{2}^{H}\left(z^{H}, \omega^{H}\right)$ and $T^{H}\left(z^{H}\right)$. Therefore, if the foreign country defaults, which goes along a rollover freeze of foreign debt, the consumption and the tax revenue in the home country decreases because the countries are interdependent. We focus on a case where there is a high degree of interdependence between the countries.

Assumption 5. $\lambda \geq \frac{c_{2}^{*}-c_{1}^{*}}{c_{2}^{*}} \frac{\ell I}{\pi c_{1}^{*}}$

The assumption implies that interdependence, measured by $\lambda$, is so strong that whenever there is a sovereign default abroad, there also is a bank run at home - unless home depositors are kept from running by a deposit insurance scheme. A high $\lambda$ implies that once the foreign government defaults, losses of banks at home on the foreign government bonds are also high. Assumption 5 implies a default abroad in fact induces a liquidation that would lower the late consumption to a level below the promised amount of early consumption, $c_{2}<c_{1}^{*}$, giving patient consumers an incentive to withdraw early. For a formal analysis, see the proof of Proposition 3 in the Appendix.

\subsection{International Contagion}

Let us first assume that countries do not intervene abroad, but only provide a deposit insurance scheme to domestic depositors. As mentioned above, we refer to this as a political autarky. We analyze how a sovereign default abroad (i.e., $\eta^{F}=0$, possible whenever $E^{F}<B$ ) may be contagious and affect outcomes in the home country. In doing so, we implicitly characterize the crisis equilibrium of the two-country economy.

Whenever there is a sovereign default abroad, the amount required to make a deposit insurance at home credible is given by $\widetilde{D I}=D I+\lambda \alpha B$. This amount is larger than in the single-country case. In order to make the deposit insurance scheme credible in the two-country case, the home country's government has to be able to cover the losses on foreign government bonds in addition to the cost of the deposit insurance, as specified in the single-country setup.

Proposition 3. In a Nash equilibrium in which there is a sovereign default in the foreign country, the following outcomes prevail in the home country: 


$$
\begin{array}{ll}
E^{H}<B & \text { Sovereign default and bank run }\left(\omega^{H}, \eta^{H}\right)=(1,0): \text { All con- } \\
& \text { sumers withdraw early and there is no rollover, inducing full liq- } \\
& \text { uidation and thus resulting in illiquidity and insolvency of both } \\
& \text { the government and the banking sector. } \\
E^{H} \in[B, B+\widetilde{D I}) & \text { Bank } \text { run }\left(\omega^{H}, \eta^{H}\right)=(1, \alpha B) \text { : Investors purchase government } \\
& \text { debt, but all consumers withdraw early. Although there is full } \\
& \text { liquidation, the government is still able fully to serve its debt. } \\
E^{H} \geq B+\widetilde{D I} \quad & \text { No bank run, but costly deposit insurance }\left(\omega^{H}, \eta^{H}\right)= \\
& (\pi, \alpha B) \text { : Investors purchase government debt, and only impa- } \\
& \text { tient consumers withdraw early. However, the deposit insurance } \\
& \text { scheme becomes costly. }
\end{array}
$$

The proof of Proposition 3 can be found in the Appendix. Let us discuss these results in some more depth. In the first case, the home country has weak fiscal fundamentals; a sovereign debt crisis abroad will always trigger a twin crisis in the home country as well. In the second case, $E^{H}$ is in an intermediate range and the home country can repay its debt for sure, but it cannot provide a credible deposit insurance. In this case, banks in the home country make a loss of $\lambda \pi c_{1}^{*}=\lambda \alpha B$, forcing them to liquidate a share of their loan portfolio, which triggers a bank run. Finally, in the third case, the fiscal fundamentals are strong and the home country can credibly promise to repay its debt and insure its deposits. Therefore, the home country can rule out a bank run at home once the foreign country defaults. However, the crisis abroad remains contagious in that banks incur a loss of $\lambda \alpha B$. Because the remaining funds of banks in $t=2$ are smaller than $(1-\pi) c_{1}^{*}$ by Assumption 5 , the deposit insurance scheme has to step in. The results of Proposition 3 are depicted in the lower area of Figure 3 , for $E^{F}<B$. The three different scenarios are represented by the areas I to III.

\subsection{Optimal Policies: Supranational Institutions}

We have seen that a crisis abroad causes real losses for home banks and is thus contagious under political autarky even if the home government is able to provide a credible deposit insurance. However, it might be possible to prevent the crisis abroad through the implementation of adequate supranational institutions. We are looking for institutions that constitute a Pareto improvement compared to the situation of political autarky, in the sense that both countries weakly benefit from this policy. We focus on two different institutional setups: first, the implementation of a banking union, and second, the joint implementation of a banking union and a fiscal union. In our model, a banking union 


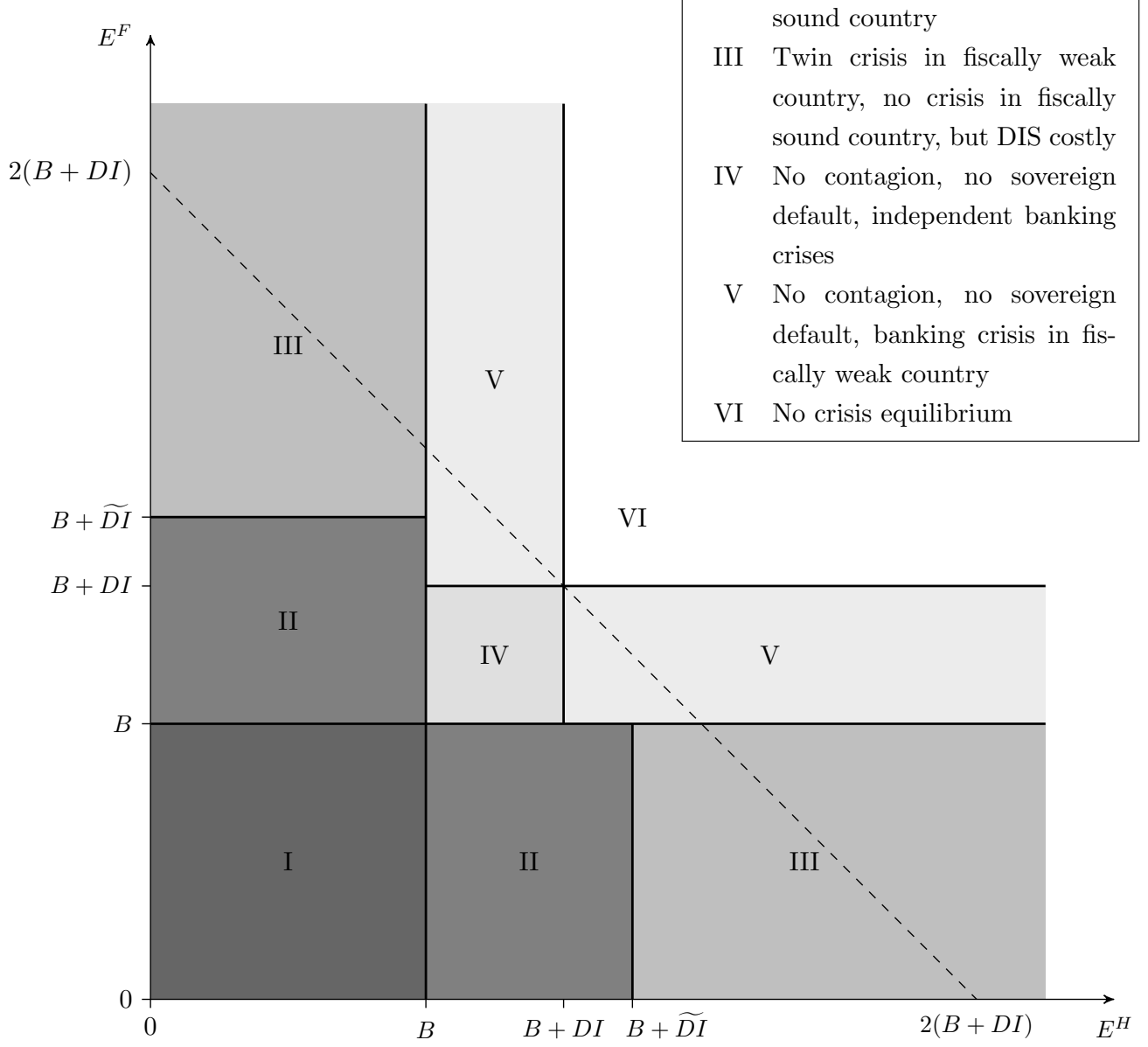

Figure 3: This figure depicts the types of crisis equilibria in the case of political autarky (each government only provides a DIS for domestic depositors) for different values of external tax revenues $E^{H}$ and $E^{F}$. In region $I$, the crisis equilibrium is a twin crisis (sovereign default and bank run) in both countries. In region II, the fiscally weak country defaults and experiences a bank run, while the fiscally sound country does not default, but experiences a banking crisis. In region III, there is a twin crisis in the fiscally weak country and no crisis in the fiscally sound country, but the DIS is costly. In region IV, one country or both countries experience a banking crisis, but sovereigns do not default and there is no contagion. The banking crises can occur independently of each other. In region $V$, there is a banking crisis in the fiscally weak country, but no contagion, and no crisis in the fiscally sound country. In region VI, no crisis equilibrium exists. 
describes a supranational institution that provides a deposit insurance scheme for both countries and is financed by both countries. Similarly, in a fiscal union, both countries mutualize sovereign debt and promise to repay the debt of both countries together.

Proposition 4. Assume $E^{H}+E^{F} \geq 2(B+D I)$ and $E^{H}>E^{F}$.

$$
\begin{array}{ll}
E^{F}<\widetilde{E} & \begin{array}{l}
\text { A banking union is Pareto-efficient only if it is complemented } \\
\text { with a fiscal union. }
\end{array} \\
E^{F} \in[\widetilde{E}, B+D I) & \begin{array}{l}
\text { A banking union is required for Pareto efficiency, but a fiscal } \\
\text { union is not necessary. }
\end{array} \\
E^{F} \geq B+D I & \begin{array}{l}
\text { Remaining in political autarky is Pareto-efficient, there is no } \\
\text { need for a banking or fiscal union. }
\end{array}
\end{array}
$$

The threshold $\widetilde{E}$ is defined as $\widetilde{E}=B-\frac{\left[\ell I-(1-\lambda) \pi c_{1}^{*}\right]^{+}}{\ell I} \tau R I$.

The assumption of $E^{H}+E^{F} \geq 2(B+D I)$ implies that the pooled exogenous tax revenues of both countries suffice to repay the government debt and credibly to insure the depositors of both countries. Let us go backwards to illustrate the results of Proposition 4. If $E^{F} \geq B+D I$, the foreign government is fiscally sound and can prevent a crisis by providing a deposit insurance scheme on its own, so Pareto efficiency is already attained under political autarky. As soon as $E^{F}<B+D I$, the foreign country cannot provide a credible deposit insurance any more and a bank run can occur. Therefore, a joint deposit insurance is needed. Based on the level of $E^{F}$, we have to make one further case distinction. Notice that even though the banking union prevents a bank run, banks might have to liquidate because of a rollover freeze. The rollover freeze can only occur if $E^{F}<\widetilde{E}$. As long as $E^{F}$ is above this threshold, the remaining tax revenue after liquidation suffices to repay the government bonds $B$. Because the rollover freeze is ruled out, the banking union is a sufficient measure. However, if the exogenous tax revenue falls below this threshold, the rollover freeze can only be ruled out by the additional implementation of a fiscal union through which the home government guarantees the repayment of foreign government debt.

The results are depicted in Figure 4. Proposition 4 is concerned with the area above the dashed line, where $E^{H}+E^{F} \geq 2(B+D I)$. In region (i) no union is required. A banking union is strict Pareto improvement in regions (ii) and (iii), whereas in region (iv) the implementation of both a banking and a fiscal union is required.

We conclude that if the countries are sufficiently different with respect to their exogenous tax revenue, it may be beneficial for both countries to form a banking union as this eliminates the adverse crisis equilibrium at no costs. 


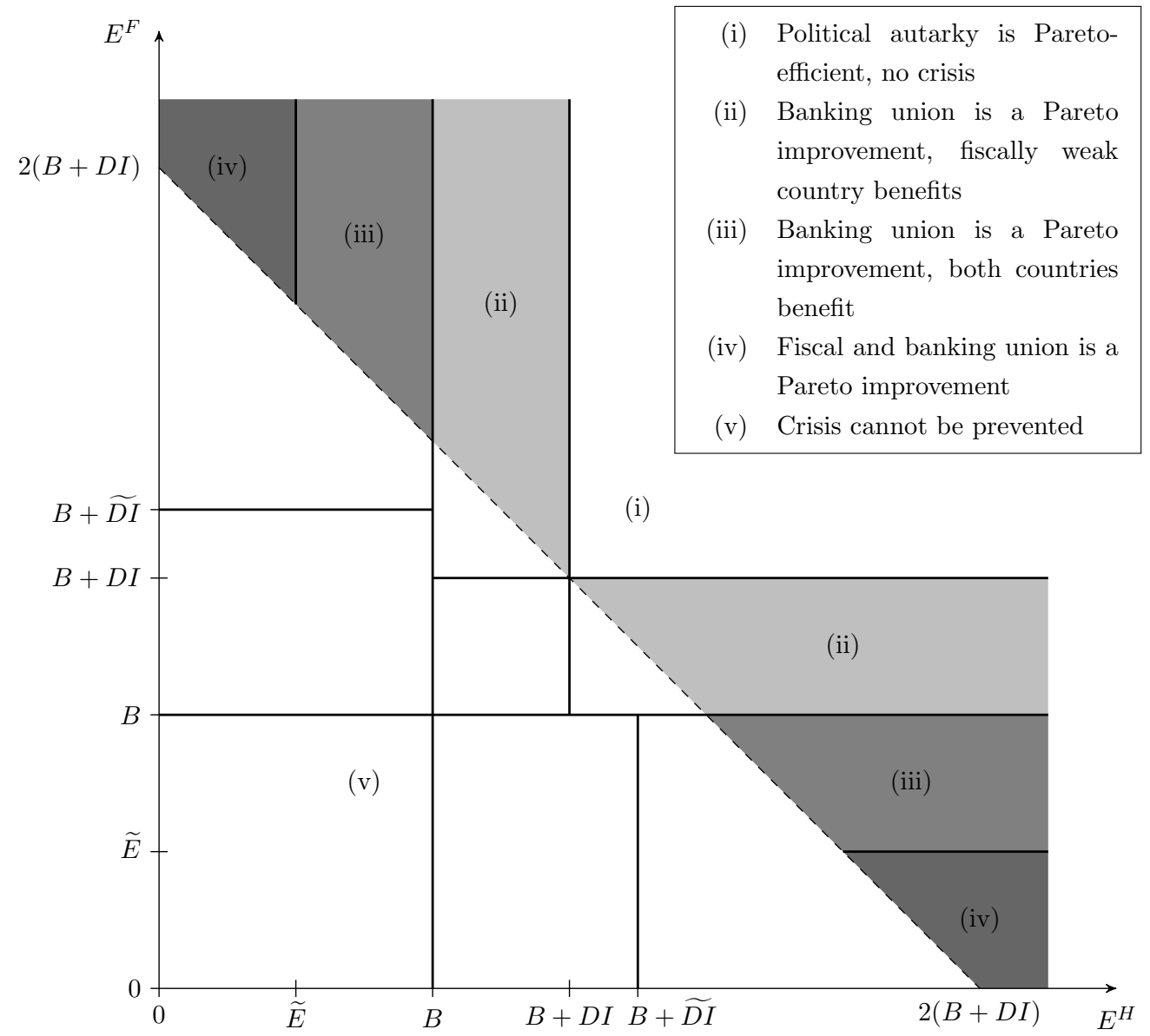

Figure 4: This figure depicts regions in which the crisis equilibrium can be eliminated by either a banking union or the joint implementation of a Banking and fiscal union for different values of external tax revenues $E^{H}$ and $E^{F}$. In region (i), a crisis equilibrium does not exist even under political autarky, thus a union is not needed. In region (ii), a banking union stabilizes the weaker country by ruling out a bank run. While it does not benefit the stronger country, it does not cost anything either. In region (iii), the banking union rules out a bank run and a sovereign default of the weaker country, thus benefiting both countries. Finally, in region (iv), the banking union is not effective anymore. Here, only the joint implementation of banking and fiscal union can eliminate the crisis, and it is costless for both countries. If the sum of exogenous tax revenues is too small, it is not possible to rule out crisis equilibria by forming a union (region (v)). While the fiscally stronger country might experience neither a sovereign default nor a bank run, it suffers whenever the weaker country experiences a sovereign default. 


\section{Discussion}

Notice that there is no uncertainty regarding fiscal soundness in our model, i.e., it is clear which country is fiscally weak and which country is fiscally strong. However, both countries have an incentive to form a banking union or even a fiscal union. The type of unions discussed can therefore be understood as something that is different from typical insurance against potential adverse states in the future. A typical insurance would be a contract between agents which is signed before relevant states are realized and which aims at insuring at least one of the contracting parties. Typically, there is ex post one party that makes losses on the contract because it has to transfer net funds to the other party.

In our case, however, the insurance contract can be signed after the values of external tax revenues, $E^{H}$ and $E^{F}$, are realized because there is no transfer of funds from the strong to the weak country. In contrast, both countries benefit from this atypical insurance even ex post, even though the union might be valued more by the fiscally weak than by the fiscally strong country. Because it is effective in preventing self-fulfilling crises, the unions are costless for both countries. This consideration implies that if there was initial uncertainty about which of the two countries is the strong one and which is the weak one, both countries would have an incentive to form the union.

\section{The European Banking Union}

We now use the insights of our model to investigate the efficacy of recent policy proposals. The proclaimed goal of the proposal for the implementation of a banking union in the euro area is to ensure financial stability and to break the "potentially vicious circle between banks and sovereigns" (European Commission, 2013a).

The current proposals for the formation of a banking union consist of three components. First, the Single Supervisory Mechanism (SSM), which is supposed to be complemented by a single rulebook of the European Banking Authority (Council of the European Union, 2013). Second, the Single Resolution Mechanism (SRM) for the centralization of competencies and resources for managing the failure of banks (European Commission, 2013b). Third, a supranational Deposit Guarantee Scheme (DGS).

Currently, the first two components are already implemented (SSM) or close to being implemented (SRM), but a supranational deposit insurance scheme so far seems to be politically infeasible and is currently off the table (European Commission, 2013a). Hellwig (2014) points out several doubts about the effectiveness of SSM and SRM at dealing with cross-boarder externalities, especially for the case of banks that operate in 
several countries. Furthermore, he points out that national authorities may be unable or unwilling to provide funding in case of a crisis, calling for a fiscal backstop at the European level. Our model points to a further problem: We show that the lack of a supranational DGS may be a serious shortcoming of the European Banking Union, and may undermine the overall efficacy of the proposed reforms in ensuring financial stability.

Note that due to the stylized nature of our model there is no role for supervision and resolution of banks. Thus, our model remains silent on the efficacy of the components of the banking union that have already been or are about to be implemented (supervision and resolution). Clearly, both components are crucial for harmonizing banking regulation on the European level and may well be considered as a key achievement.

In turn, our model can actually say something on the supranational DGS, the component policy makers currently seem to refuse to implement. Our model states that if there is sufficient interdependence between countries and a high degree of heterogeneity in the countries' fiscal soundness, a banking union as well as a fiscal union may eliminate the self-fulfilling crisis equilibrium. Observe that in fact banks are highly interconnected within the euro area. Moreover, observe that there are countries that may be considered fiscally sound (e.g., Germany and France), and others that may be considered fiscally weak (e.g., Spain and Italy) 9 If one is willing to believe in the self-fulfilling nature of financial crises, a deposit insurance scheme, potentially complemented by a fiscal union, may implement financial stability at no costs. This also implies that the refusal to implement a deposit insurance scheme may lead to potentially costly contagion across countries, which could be avoided.

A deposit insurance scheme works best if it is credible and never tested and thus eliminates the possibility of self-fulfilling crises at no costs. In order to understand the importance of this insight in the context of the European situation, consider the following: Assume that there is a fiscally sound country that would never experience a self-fulfilling crisis if it was in autarky. However, its interdependence with another country implies its banks will realize losses once there is a crisis in the foreign country. Thus, ensuring domestic financial stability through, e.g., a deposit insurance scheme will become costly for the government once its banks have realized losses. A crisis abroad may therefore cause real costs at home once there is sufficient interdependence. Given the self-fulfilling nature of the crisis abroad, it may be optimal for the home country to participate in a mechanism that prevents the crisis abroad at low (or even at zero) costs.

\footnotetext{
${ }^{9}$ We do not consider our model to fit the case of Greece. It is more than questionable whether Greece could have repaid its debt even if its debt had been a rolled over. The crisis in Greece does not appear to be only self-fulfilling, but rather due to fundamental problems. Greece and Portugal rather had "old-fashioned sovereign debt crises" (Hellwig, 2014).
} 
Preventing the crisis abroad eliminates contagion and thus ensures financial stability at home in this setting. Our model shows that this is possible by implementing a banking union (equivalent to a joint deposit insurance scheme in our model) which is complemented with a fiscal union if necessary.

In order to apply this insight to the European situation, one needs to appreciate the fact that a deposit insurance in fiscally weak countries may not be credible. It may therefore not be able to prevent a banking crisis in the respective country, a crisis that can be contagious and thus costly for fiscally sound countries as well. A banking union with a joint deposit insurance scheme may increase the credibility of the deposit insurance. In fact, the deposit insurance scheme may become fully credible once it is backed by fiscally sound governments, eliminating the crisis equilibrium altogether. In fact, in our very simple setup, such a mechanism can eliminate the crisis equilibrium at no cost.

One may hypothesize that politicians in fiscally sound countries currently seem to be scared of implementing a joint deposit insurance scheme. The rationale is that it could appeal to voters as another form of mutualization of national debt, with a clear disadvantage for taxpayers in fiscally sound countries. E.g., German politicians may fear to scare their voters as a banking union may imply that German tax payer can potentially be liable for losses of, e.g., Spanish banks. Our model indicates that this may turn out to be bitter irony: exactly the refusal of implementing a full-fledged banking union with a joint deposit insurance scheme may make future crises more costly for the respective tax payers.

\section{Conclusion}

Our model has two main contributions. First, we discuss how banking crises and sovereign defaults can be contagious across countries. The setup allows us to rationalize supranational policies that aim at preventing sovereign and financial crises. Our specific setup gives conditions under which a fiscal and a banking union are effective measures to eliminate an adverse run equilibrium. We use these results to comment on the policy debates on the making of a banking union in the euro area. Importantly, our model indicates that a banking union with a joint deposit insurance scheme may be a mechanism to prevent contagious self-fulfilling banking crises. It possibly has to be complemented by a fiscal union to be entirely effective. We argue that the current proposal for a banking union, consisting only of supranational supervision and resolution mechanisms, is insufficient to break the vicious cycle between sovereigns and banks. 
Second, the model illustrates the risks associated with banks holding government bonds. In our model, fragility arises whenever the fate of the government and the financial sector are closely connected. This condition is likely met in developed and highly leveraged financial systems where banks hold government bonds and where economic activity depends on the performance of the financial sector. Our paper thus sheds light on the debate regarding the regulation of government bonds holding by intermediaries. More specifically, it gives a rationale for why exposure of banks to sovereign risk may be problematic.

The stylized nature of our model implies that our insights and policy implications have to be taken with a grain of salt and cannot be translated one-to-one for every institutional arrangement. In our model, we abstract from fundamental uncertainty (i.e., macroeconomic shocks) as a source of a crisis, and from potential moral hazard resulting from an established banking and fiscal union. Both elements may be of importance in reality. For the case of negative macroeconomic shocks in a foreign country, a supranational deposit insurance may moderate a crisis, but this might come with real costs for the home country. In addition, the presence of an international insurance may induce a country's institutions (government, supervision, and banks) to gamble. Both aspects might induce fiscally strong countries to refrain from a fiscal and an extensive banking union. This is not an argument against such unions, though. It rather calls for detailed contractual definitions of the union's scope, and for strict regulation and supervision that is located at level of the union. The SSM and SRM can mitigate such moral hazard on the country level, and thus build the foundation which is necessary for implementing a supranational DGS. 


\section{References}

Acharya, Viral V., and Raghuram G. Rajan (2013). "Sovereign Debt, Government Myopia, and the Financial Sector". Review of Financial Studies 26.6, pp. 1526-1560.

Acharya, Viral V., Itmar Drechsler, and Philipp Schnabl (2014). "A Pyrrhic Victory? Bank Bailouts and Sovereign Credit Risk". The Journal of Finance, forthcoming.

Alesina, A, A Prati, and G Tabellini (1990). "Public confidence and debt management: A model and a case study of Italy". In: Debt Management and Capital Markets. Ed. by R. Dornbusch, and M. Draghi. June. Cambridge University Press, pp. 94-118.

Allen, Franklin, and Douglas Gale (1998). "Optimal Financial Crises". The Journal of Finance LIII.4, pp. 1245-1284.

- (2000). "Financial Contagion". Journal of Political Economy 108.1, pp. 1-33.

Basel Committee - Basel Committee on Banking Supervision (2011). Basel III: A global regulatory framework for more resilient banks and banking systems. June. Basel: Bank for International Settlement.

Bolton, Patrick, and Olivier Jeanne (2011). "Sovereign Default Risk and Bank Fragility in Financially Integrated Economies". IMF Economic Review 59.2, pp. 162-194.

Broner, Fernando, Alberto Martin, and Jaume Ventura (2010). "Sovereign Risk and Secondary Markets". American Economic Review 100.4, pp. 1523-1555.

Bulow, Jeremy, and Kenneth Rogoff (1989). "Sovereign Debt: Is to Forgive to Forget?" American Economic Review 79.1, pp. 43-50.

Calvo, Guillermo (1988). "Servicing the Public Debt: The Role of Expectations". American Economic Review 78.4, pp. 647-661.

Cole, Harold L., and Timothy Kehoe (2000). "Self-Fulfilling Debt Crises". Review of Economic Studies 67.1, pp. 91-116.

Cooper, Russell, and Kalin Nikolov (2013). "Government Debt and Banking Fragility: The Spreading of Strategic Uncertainty". NBER Working Paper No. 19278.

Council of the European Union (2013). "COUNCIL REGULATION (EU) No 1024/2013 of 15 October 2013 conferring specific tasks on the European Central Bank concerning policies relating to the prudential supervision of credit institutions". Official Journal of the European Union 287.1024, pp. 63-89.

Dasgupta, Amil (2004). "Financial Contagion through Capital Connections: A Model of the Origin and Spread of Bank Panics". Journal of the European Economic Association 2.6, pp. 1049-1084.

Diamond, Douglas W., and Philip H. Dybvig (1983). "Bank Runs, Deposit Insurance, and Liquidity". Journal of Political Economy 91.3, pp. 401-419. 
Eaton, Jonathan, and Mark Gersovitz (1981). "Debt with Potential Repudiation: Theoretical and Empirical Analysis". Review of Economic Studies 48.2, pp. 289-309.

European Commission (2013a). A comprehensive EU response to the financial crisis: substantial progress towards a strong financial framework for Europe and a banking union for the eurozone. December, MEMO.

(2013b). Establishing uniform rules and a uniform procedure for the resolution of credit institutions and certain investment firms in the framework of a Single Resolution Mechanism and a Single Bank Resolution Fund and amending Regulation (EU) No 1093/2010. Proposal for a Regulation of the European Parliament and of the Council.

Farhi, Emmanuel, and Jean Tirole (2014). "Deadly Embrace: Sovereign and Financial Balance Sheets Doom Loops". Working Paper.

Flannery, Mark J. (1996). "Financial Crises, Payment System Problems, and Discount Window Lending". Journal of Money, Credit and Banking 28.4, pp. 804-824.

Gale, Douglas (1990). "The Efficient Design of Public Debt". In: Public debt management: theory and history. Ed. by Rudiger Dornbusch, and Mario Draghi. Cambridge University Press.

Gennaioli, Nicola, Alberto Martin, and Stefano Rossi (2014). "Sovereign Default, Domestic Banks, and Financial Institutions". The Journal of Finance LXIX.2, pp. 819866.

Goldstein, Itay (2005). "Strategic Complementarities and the Twin Crises". Economic Journal 115, pp. 368-390.

Goldstein, Itay, and Ady Pauzner (2005). "Demand-Deposit Contracts and the Probability of Bank Runs". The Journal of Finance LX.3, pp. 1293-1327.

Goodhart, Charles (2011). The Basel Committee on Banking Supervision: A History of the Early Years 1974-1997. Cambridge University Press.

Gorton, Gary B., and G Ordoñez (2013). "The Supply and Demand for Safe Assets". NBER Working Paper No. 18732.

Guembel, Alexander, and Oren Sussman (2009). "Sovereign Debt without Default Penalties". Review of Economic Studies 76.4, pp. 1297-1320.

Hart, Oliver, and John Moore (1994). "A Theory of Debt Based on the Inalienability of Human Capital". Quarterly Journal of Economics 109.4, pp. 841-879.

Hellwig, Martin (2014). "Yes Virginia, There is a European Banking Union! But It May Not Make Your Wishes Come True". Preprint of the Max Planck Institute for Research on Collective Goods Bonn No. 2014/12. 
Holmström, Bengt, and Jean Tirole (1997). "Financial Intermediation, Loanable Funds, and the Real Sector". Quarterly Journal of Economics 112.3, pp. 663-691.

- (1998). "Private and Public Supply of Liquidity". Journal of Political Economy 106.1, pp. 1-40.

König, Philipp, Kartik Anand, and Frank Heinemann (2013). "The 'Celtic Crisis': Guarantees, Transparency, and Systemic Liquidity Risk". SFB 649 Discussion Paper 2013-025.

Leonello, Agnese (2013). "Government Guarantees and the Two-Way Feedback between Banking and Sovereign Debt Crises". Working Paper.

Luck, Stephan, and Paul Schempp (2014). "Outside Liquidity, Rollover Risk, and Government Bonds". Preprint of the Max Planck Institute for Research on Collective Goods Bonn No. 2014/14.

Reinhart, Carmen M., and Kenneth S. Rogoff (2009). "The Aftermath of Financial Crises". American Economic Review 99.2, pp. 466-472.

(2011). "From Financial Crash to Debt Crisis". American Economic Review 101.August, pp. 1676-1706.

Rochet, Jean-Charles, and Xavier Vives (2004). "Coordination Failures and the Lender of Last Resort: Was Bagehot Right After All?" Journal of the European Economic Association 2.6, pp. 1116-1147.

Uhlig, Harald (2010). "A Model of a Systemic Bank Run". Journal of Monetary Economics 57.1, pp. 78-96.

Woodford, Michael (1990). "Public Debt as Private Liquidity". American Economic Review 80.2, pp. 382-388. 


\section{Appendix A Proofs}

Proof of Proposition 1. We first analyze proof the existence of the Type I equilibrium where $(\omega, \eta)=(\pi, \alpha B)$ : By Equation (1), banks do not engage in liquidation, $z(\omega, \eta)=0$, yielding a late consumption of $c_{2}=c_{2}^{*}$ and a tax revenue of $T=E+\tau R I$. Assumptions 1 to 3 , and Equations (2) and (3) imply that patient consumers do not withdraw early, $\omega_{i}^{*}(\omega, \eta)=0 \forall i$, and outside investors roll over the debt $\eta_{j}^{*}(\omega, \eta)=1 \forall j$. Therefore $(\omega, \eta)=\left(\pi, \pi c_{1}^{*}\right)$ constitutes a Nash Equilibrium.

We now proof the existence of the Type II equilibrium. We distinguish two cases.

$E<B$ Sovereign default and bank run $(\omega, \eta)=(1,0)$ :

The liquidation is given by $z(\omega, \eta)=1$, yielding $c_{2}=0$ and $T=E$. We get $\omega_{i}^{*}(\omega, \eta)=$ $1 \forall i$ and $\eta_{j}^{*}(\omega, \eta)=0 \forall j$. Therefore $(\omega, \eta)=(1,0)$ constitutes a Nash Equilibrium.

$E \geq B$ Bank run $(\omega, \eta)=(1, \alpha B)$ :

The liquidation is given by $z(\omega, \eta)=1$, yielding $c_{2}=0$ and $T=E$. We get $\omega_{i}^{*}(\omega, \eta)=$ $1 \forall i$ and $\eta_{j}^{*}(\omega, \eta)=1 \forall j$. Therefore $(\omega, \eta)=(1, \alpha B)$ constitutes a Nash Equilibrium.

Proof of Proposition 3. A sovereign default in the foreign country implies that $\eta^{F}=0$, implying that domestic banks make a loss of $(1-h) \alpha B$. Assumption 5 implies that this loss induces a liquidation which necessarily triggers a bank run in the home country in the absence of the a deposit insurance. To prove this fact, we show that even if there was rollover of sovereign debt and no run, depositors would still prefer to run, i.e., $c_{2}^{H}<c_{1}^{*}$. In this case, the liquidation would be $z^{H}(\pi, \alpha B, 0)=\left(\pi c_{1}^{*}-(1-\lambda) \pi c_{1}^{*}\right) / \ell I=\lambda \pi c_{1}^{*} / \ell I$. By Assumption 5, it follows that $z^{H}>\frac{c_{2}^{*}-c_{1}^{*}}{c_{2}^{*}}=1-\frac{c_{1}^{*}}{c_{2}^{*}}$. Late consumption is given by $c_{2}^{H}\left(z^{H}, \pi\right)=\left(1-z^{H}\right) c_{2}^{*}$. It follows that $c_{2}^{H}\left(z^{H}, \pi\right)<\left(c_{1}^{*} / c_{2}^{*}\right) c_{2}^{*}=c_{1}^{*}$. Therefore, the bank run is inevitable in the absence of a deposit insurance.

$E^{H}<B$ : Sovereign default and bank run, $\left(\omega^{H}, \eta^{H}\right)=(1,0)$

Because the government cannot provide a deposit insurance, a bank run is triggered. This leads to full liquidation and reduces the tax revenue to $T^{H}=E^{H}<B$, inducing a sovereign default and a rollover freeze.

$E^{H} \in[B, B+\widetilde{D I}):$ Bank run, $\left(\omega^{H}, \eta^{H}\right)=(1, \alpha B)$

Because the government cannot provide a deposit insurance, a bank run is triggered. This leads to full liquidation and reduces the tax revenue to $T^{H}=E^{H}>B$. The sovereign can repay its debt, and rollover is ensured. 
$E^{H} \geq B+\widetilde{D I}$ : No Bank run but costly deposit insurance, $\left(\omega^{H}, \eta^{H}\right)=(\pi, \alpha B)$

The government can provide a deposit insurance scheme and thus prevent a bank run, and it can also repay its debt, ensuring the rollover of debt. However, the deposit insurance is costly.

Proof of Proposition 4. Given that $E^{F} \geq B+D I$, it is immediately clear that both countries are stable under political autarky, therefore a union is not needed.

In the presence of a banking union, the foreign government cannot experience a sovereign debt crisis if $E^{F} \geq \widetilde{E}$. Because joint funds suffice to make a banking union credible, it prevents a run in the foreign country. If there was a rollover freeze in the foreign country, banks would have to liquidate $z^{F}(\pi, 0, \alpha B)=\min \left[1,(1-\lambda) \pi c_{1}^{*} /(\ell I)\right]$. This induces a tax revenue of $T^{F}\left(z^{F}\right) \geq \widetilde{E}+\frac{\left[\ell I-(1-\lambda) \pi c_{1}^{*}\right]^{+}}{\ell I} \tau R I=B$. The foreign government can thus repay its debt, and a rollover freeze cannot occur in equilibrium. Therefore, the banking union is sufficient to eliminate any crisis altogether if $E^{F} \geq \widetilde{E}$.

If however $E^{F}<\widetilde{E}$, a rollover freeze constitutes an equilibrium even in the presence of a banking union which prevents a bank run. In case of a rollover freeze, the tax revenue is given by $T^{F}\left(z^{F}\right)<\widetilde{E}+\frac{\left[\ell I-(1-\lambda) \pi c_{1}^{*}\right]^{+}}{\ell I} \tau R I=B$. Therefore, the joint implementation of the banking and the fiscal union is required. This policy measure is costless for the home country because by providing the deposit insurance and guaranteeing to repay all government debt, it rules out a bank run and ensures rollover of foreign government debt. The deposit insurance will not be tested, and because foreign banks do not engage in liquidation, the foreign government has sufficient tax revenue to repay its debt by itself.

Returning to the case of $E^{F} \in[\widetilde{E}, B-D I]$, we can distinguish two different scenarios. If $E^{F} \in[\widetilde{E}, B]$, both countries strictly benefit from the implementation of the banking union. The foreign country does not experience any crisis, and because the default of the foreign sovereign is ruled out, losses of home banks on foreign government bonds are eliminated. In contrast, if $E^{F} \in[B, B+D I)$, the foreign country will always be able to repay its debt. Therefore, the home country cannot be affected by a crisis at all. Even if there was a bank run in the foreign country, the home country would not suffer because the exposure is only through foreign debt which is unaffected. Thus, only the foreign country benefits from the banking union, but the home country does not suffer. This distinction is illustrated by the regions (ii) and (iii) in Figure 4. 